ఠ

\title{
Role and development of GLP-I receptor agonists in the management of diabetes
}

This article was published in the following Dove Press journal:

Diabetes, Metabolic Syndrome and Obesity:Targets and Therapy

15 May 2009

Number of times this article has been viewed

\section{Chee W Chia \\ Josephine M Egan}

National Institutes of Health, National Institute on Aging, Intramural Research Program, Baltimore, Maryland, USA
Correspondence: Josephine M. Egan National Institute on Aging, Intramural Research Program, Biomedical Research Center, 25I Bayview Boulevard, Baltimore, MD 21224, USA

Tel + I $41055884 \mid 4$

Fax + I 410558838 I

Email eganj@grc.nia.nih.gov
Abstract: Glucagon-like peptide-1 (GLP-1) is a hormone secreted from enteroendocrine L cells of the intestine in response to food. Exogenous GLP-1 administration at pharmacological doses results in many effects that are beneficial for treating type 2 diabetes, these include: (1) an increase in insulin secretion from $\beta$ cells; (2) a suppression of glucagon secretion from $\alpha$ cells in the presence of hyperglycemia but not hypoglycemia; (3) a delay in gastric emptying and gut motility which in turns delays absorption of ingested nutrients and dampens post-prandial glucose excursion; and (4) an increase in the duration of postprandial satiety therefore suppressing appetite and decreasing food intake which eventually leads to weight loss. However, GLP-1 is subject to rapid enzymatic degradation, and therefore, not suitable for long-term treatment. A synthetic enzyme-resistant GLP-1 receptor agonist that reproduces the biological effects of GLP-1 is in use and more are under development. This review aims at providing a summary of the properties of GLP-1 and the development of GLP-1-based therapies for treatment of diabetes.

Keywords: incretin, GLP-1, GLP-1R agonist, diabetes

\section{Introduction}

\section{What are incretins?}

The incretin effect describes the augmentation in insulin secretion that occurs in response to oral glucose compared to intravenous glucose ${ }^{1-3}$ Incretins, therefore by definition, are gut-derived factors that stimulate insulin secretion from $\beta$ cells after eating. The two hormones that fulfill criteria as incretins are glucose-dependent insulinotropic polypeptide (GIP) and glucagon-like peptide-1 (GLP-1).

GIP is a 42-amino acid peptide synthesized and released from enteroendocrine $\mathrm{K}$ cells mostly located in the duodenum and upper jejunum. ${ }^{4}$ GLP-1, a product of the proglucagon gene, exists in two bioactive forms, GLP-1 (7-36) amide and GLP-1 (7-37), with GLP-1 (7-36) comprising up to $80 \%$ of the GLP-1 in circulation. ${ }^{5}$ It is released from enteroendocrine $L$ cells dispersed throughout the gastrointestinal tract. ${ }^{6,7}$ Together, the insulinotropic effect of GLP-1 and GIP accounts for up to $60 \%$ of the insulin secreted after a meal in healthy humans and plays a very important role in postprandial glucose homeostasis. ${ }^{8}$

In patients with type 2 diabetes mellitus (T2DM), the ability of exogenous GIP and GLP-1 to stimulate insulin secretion is diminished by $54 \%$ and $29 \%$, respectively, when compared to healthy subjects. However, the glucose lowering effect of GLP-1 is relatively preserved while that of GIP is absent. ${ }^{9-11}$ Therefore, development of therapeutic strategies for T2DM has focused on GLP-1 and not GIP. 


\section{Physiology of GLP-I}

Fat and carbohydrate-rich meals are the primary physiological stimuli to GLP-1 secretion from enteroendocrine cells. ${ }^{12}$ Recently, artificial sweeteners, such as sucralose, have also been shown to induce GLP-1 secretion from L cells. ${ }^{13}$ Although GLP-1 has been found in taste buds and brain tissues, the majority of the GLP-1 measured in peripheral blood is synthesized in L cells. ${ }^{7}$

In healthy subjects, fasting levels of plasma GLP-1 range from 5-10 pmol/L and increase by two- to three-fold after meal ingestion. ${ }^{14}$ GLP-1 levels peak about 20 min after oral glucose administration and about 60 to $90 \mathrm{~min}$ after mixed meal ingestion, and the levels gradually decline toward fasting levels thereafter. ${ }^{15,16}$ GLP-1 stimulates insulin secretion in a glucose concentration dependent manner; its insulinotropic effect is lost at plasma glucose concentration below $4.3 \mathrm{mmol} / \mathrm{L}(77 \mathrm{mg} / \mathrm{dL}) .{ }^{17}$

In earlier studies, patients with long-standing T2DM and poor glycemic control $\left(\mathrm{HbA}_{1 \mathrm{c}} \sim 9.2 \%\right)$ were noted to have deficient GLP-1 secretion. ${ }^{18,19}$ Recent studies have shown that GLP-1 levels are similar among subjects with mild T2DM $\left(\mathrm{HbA}_{1 \mathrm{c}} \sim 6.8 \%\right)$, impaired glucose tolerance, and normal glucose tolerance. ${ }^{15,16}$ Therefore, GLP-1 secretion in patients with T2DM appears to depend on their glycemic status, their medication intake, and other hormonal and metabolic abnormalities associated with worsening glycemic control. ${ }^{16}$

GLP-1 has a short half-life of 2 min because it is rapidly degraded by dipeptidyl peptidase 4 (DPP 4) and neutral endopeptidase (NEP) 24.11. ${ }^{20-22}$ DPP 4 cleaves the N-terminal dipeptides $\left(\mathrm{His}^{7}-\mathrm{Ala}^{8}\right)$ from GLP-1 (7-36) and renders the resulting major metabolite GLP-1 (9-36) insulinotropically inactive ${ }^{20,23}$ NEP 24.11, a membrane-bound zinc metallopeptidase, also degrades GLP-1 at potentially six cleavage sites. ${ }^{21}$ High levels of NEP 24.11 are found in the kidney, and GLP-1 and its metabolites are rapidly cleared through the kidneys. ${ }^{24}$

The action of GLP-1 is mediated through the glucagonlike peptide-1 receptor (GLP-1R), a seven-member trans-membrane $\mathrm{G}$ protein-coupled receptor. ${ }^{25} \mathrm{GLP}-1 \mathrm{R}$ is expressed in a variety of tissues including pancreatic $\beta$ cells, hypothalamus, hippocampus, area postrema and various other parts of the brain, as well as stomach, heart, intestine, and kidney. ${ }^{26}$

\section{GLP-I-based therapy in T2DM}

Regardless of the post-prandial levels of GLP-1 in T2DM, the insulin response to GLP-1 is still defective. The response of $\beta$ cells to exogenously administered GLP-1 was noted to be three to five times lower in patients with T2DM when compared to healthy subjects. ${ }^{11,27}$ Despite the diminished response of $\beta$ cells to exogenous GLP-1, overnight intravenous infusion of GLP-1 in patients with T2DM was able to lower fasting and post-prandial plasma glucose to near-normal levels, to improve $\beta$-cell function, and to restore first-phase insulin secretion. ${ }^{28}$

To examine the effect of long-term GLP-1 treatment in patients with T2DM, continuous subcutaneous GLP-1 infusion was given for six and 12 weeks using an infusion pump in two separate studies..$^{29-31}$ Both studies showed that GLP-1 infusion clearly improved $\beta$-cell function and improved insulin sensitivity. A subset of subjects in the 12-week infusion study had frequent blood sampling performed after six weeks of therapy and the results showed significant improvement in insulin pulse mass and pulsatile insulin secretion. ${ }^{31}$

Exogenous GLP-1 administration at pharmacological doses also has several noninsulinotropic effects that are beneficial for treating T2DM. With exogenous GLP-1, glucagon secretion from $\alpha$ cells was suppressed in the presence of hyperglycemia and euglycemia but not hypoglycemia. The suppression of glucagon leads to improved hepatic insulin resistance and glycemic control in T2DM. ${ }^{17,32}$ Exogenous GLP-1 also delays gastric emptying and gut motility and these effects slow absorption of ingested nutrients and dampen post-prandial glucose excursion in patients with T2DM. ${ }^{33}$ Exogenous GLP-1 also increases the duration of postprandial satiety, decreases energy intake and suppresses appetite; leading to less food being eaten and eventually weight loss in most people..$^{29,34,35}$

Most hypoglycemic agents work by either attempting to increase insulin secretion from $\beta$ cells (sulfonylureas, meglitinides) or increasing peripheral insulin sensitivity (biguanides, thiazolidinediones). None of them actually targets the root cause of T2DM; deteriorating $\beta$-cell function and mass. In addition to stimulating insulin secretion and suppressing glucagon secretion, GLP-1 has other pleiotropic effects in the pancreas. Animal studies have suggested that chronic exogenous GLP-1 administration has the ability to increase islet size, enhance $\beta$-cell proliferation, inhibit $\beta$-cell apoptosis, and regulate islet growth. ${ }^{36,37}$ These trophic effects on $\beta$ cells have not been tested in humans as there is no direct in vivo measure of human $\beta$-cell mass available.

Using indirect measures of $\beta$-cell function, one study showed that short-term (12 hours) GLP-1 infusion improved the ability of $\beta$ cells to sense and respond to glucose in patients 
with impaired glucose tolerance. ${ }^{38}$ Overnight GLP-1 infusion also improved first- and second-phase insulin secretion in patients with T2DM. ${ }^{28}$ Six-week infusion of GLP-1 in patients with T2DM showed improvement in insulin sensitivity and $\beta$-cell function as measured by glucose utilization and first- and second-phase C-peptide response during hyperinsulinemic euglycemic clamp. ${ }^{29}$ If the trophic effects seen in rodents are indeed present in humans, treatment with GLP-1 will have tremendous implications in the field of T2DM as it directly addresses one of the fundamental defects in T2DM, that is, $\beta$-cell failure.

Collectively, the biological effects of exogenous GLP-1 increasing insulin secretion from $\beta$ cells, suppressing glucagon secretion from $\alpha$ cells, decreasing post-prandial glucose excursion through delay in gastric emptying, increasing postprandial satiety, and possibly enhancing the trophic effects on human $\beta$ cells - make GLP-1 receptor-based therapy a highly desirable treatment option for T2DM. However, the short half-life of GLP-1 (2 min) renders the native GLP-1 peptide impractical for clinical use. Two obvious options for GLP-1 receptor-based therapies are: (1) GLP-1 analogs with longer half-lives and full efficacy at the GLP-1 receptor (GLP-1R agonists); and (2) agents such as DPP 4 inhibitors that can increase plasma levels of endogenous GLP-1. In this review, we will focus on the GLP-1R agonists. So far, no headway has been made on developing drugs to specifically increase endogenous secretion of GLP-1, though a drug in common use for T2DM, metformin, does cause about a twofold increase in GLP-1 secretion. ${ }^{39}$

\section{GLP-I R agonists}

As mentioned earlier, GLP-1 has a half-life of only about 2 min because it is rapidly degraded by DPP 4 and NEP 24.11. To develop GLP-1R agonists with longer half-lives, various modifications of GLP-1 at $\mathrm{His}^{7}, \mathrm{Ala}^{8}$, or Glu${ }^{9}$ have been attempted so as to prevent DPP 4 from cleaving the first two N-terminal amino acids $\left(\mathrm{His}^{7}, \mathrm{Ala}^{8}\right)$ of native GLP-1. ${ }^{40}$ Additional mid-chain modifications of the GLP-1 peptide to prevent hydrolysis by NEP 24.11 are also being studied. Other technologies that allow gradual drug delivery at a controlled rate are also being investigated. This review will summarize the GLP-1R agonists that have clinical efficacy data published in peer-reviewed journals and presented at major scientific meetings.

\section{Exenatide}

Exenatide (synthetic exendin-4) is the only GLP-1R agonist currently approved by regulatory agencies as an adjunct therapy for patients with T2DM who are not achieving satisfactory glycemic control using other hypoglycemic agents. Exendin-4 is a 39-amino acid peptide produced in the salivary glands of the Gila monster (Heloderma suspectum) (Figure 1). It has 53\% amino acid homology to full-length GLP-1 and binds more avidly than GLP-1 to the GLP-1R. ${ }^{25}$ There appears to be no specific exendin-4 receptor; the effects of exendin- 4 are expressed through the known GLP-1 receptor. Exendin-4 has a $\mathrm{Gly}^{8}$ in place of an $\mathrm{Ala}^{8}$ of the $\mathrm{N}$-terminus, and therefore, is not a substrate for DPP 4 . In addition, it lacks some of the target bonds for NEP 24.11, and its secondary and tertiary structures may also prevent NEP 24.11 hydrolysis, thus leading to a prolonged half-life.

\section{Pharmacology}

Since exenatide is a peptide, it must be administered subcutaneously. After its subcutaneous administration, exenatide reaches a maximum plasma concentration in $2.1 \mathrm{hr}$, and the mean half-life ranges from 3.3 to $4 \mathrm{hrs} .^{41}$ It can be detected for up to $15 \mathrm{hrs}$ in the plasma after subcutaneous injection and its biological effect remains up to at least $8 \mathrm{hrs}$ after dosing. ${ }^{41}$ In a nonclinical study, it was shown to be eliminated by the kidneys through glomerular filtration. ${ }^{42}$

\section{Efficacy studies}

Three randomized, placebo-controlled, double or triple-blind, 30-week clinical trials examined the efficacy of exenatide in subjects with T2DM not achieving adequate glycemic control on metformin and/or sulfonylurea (Table 1). ${ }^{43-45}$ Patients were randomized to placebo, exenatide $5 \mu \mathrm{g}$ twice daily, or $10 \mu \mathrm{g}$ twice daily as adjuvant treatment to sulfonylurea, metformin, or sulfonylurea/metformin. In all three studies, exenatide significantly reduced $\mathrm{HbA}_{1 \mathrm{c}}$ in the treatment groups with exenatide $10 \mu \mathrm{g}$ twice daily lowered $\mathrm{HbA}_{1 \mathrm{c}}$ by $0.8 \%-0.9 \%$; exenatide $5 \mu \mathrm{g}$ twice daily lowered $\mathrm{HbA}_{1 \mathrm{c}}$ by $0.4 \%-0.6 \%$; while placebo increased $\mathrm{HbA}_{1 \mathrm{c}}$ by $0.1 \%-0.2 \%$. In the metformin/exenatide $10 \mu \mathrm{g}$ twice daily treatment arm, $41 \%$ of patients achieved $\mathrm{HbA}_{1 \mathrm{c}} \leq 7 \%$ and a mean weight loss of $2.8 \mathrm{~kg}$. In the sulfonylurea/exenatide $10 \mu \mathrm{g}$ twice daily treatment arm, $41 \%$ of patients achieved $\mathrm{HbA}_{1 \mathrm{c}}$ of $\leq 7 \%$ and a mean weight loss of $1.6 \mathrm{~kg}$. In the metformin/sulfonylurea/ exenatide $10 \mu \mathrm{g}$ twice daily treatment arm, 34\% of patients achieved $\mathrm{HbA}_{1 \mathrm{c}}$ of $\leq 7 \%$ and a mean weight loss of $1.6 \mathrm{~kg}$.

The above three trials and their open-label extensions were folded into one open-ended, open label trial. ${ }^{46}$ Results from this three-year follow-up study showed that after treating with exenatide $10 \mu \mathrm{g}$ twice daily, the $1.0 \%$ reduction in $\mathrm{HgbA}_{1 \mathrm{c}}$ was sustained; $46 \%$ of the patients maintained a 
GLP-1

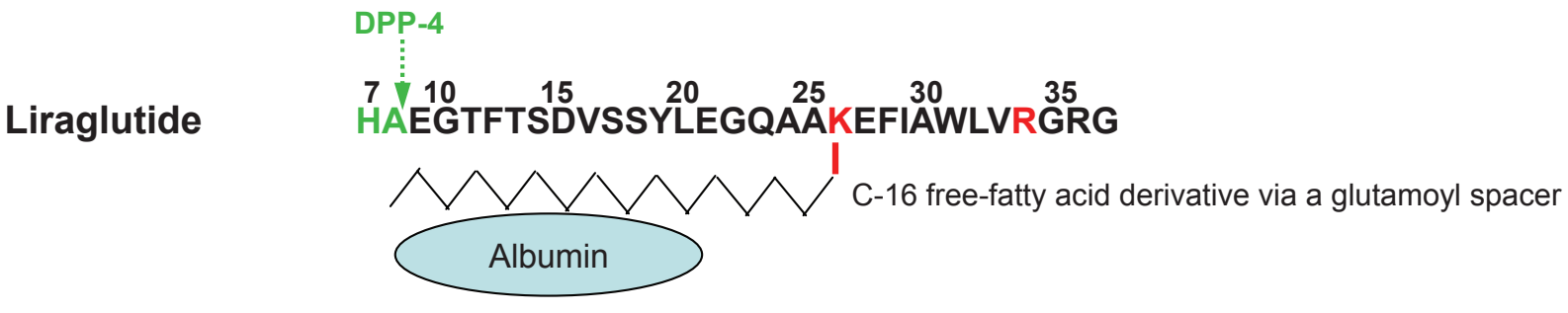

Exenatide LAR

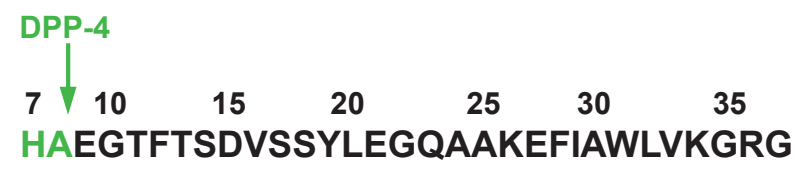

DPP-4<smiles>[C]1[CH]C1</smiles>

HGEGTFTSDLSKQMEEEAVRLFIEWLKNGGPSSGAPPPS

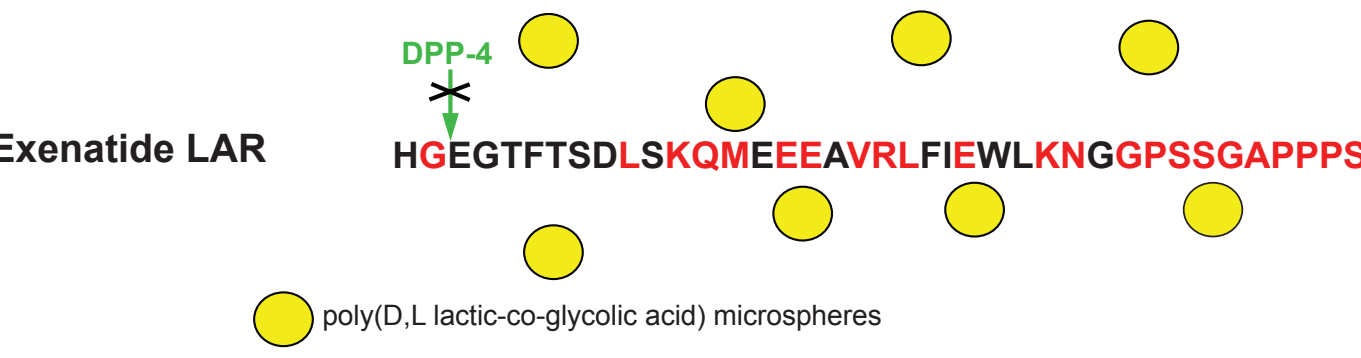

Figure I Structures of native GLP-I, exenatide, and liraglutide.The N-terminal dipeptide "HA" (in green letters) of GLP-I and liraglutide is the proteolytic cleavage site for DPP 4. Red letters indicate changes introduced in derivatives or occur naturally in exendin-4 (and replicated in the synthetic version, exenatide).A crossed-out green arrow indicates absent DPP 4 activity, and a dotted green arrow indicates reduced DPP 4 activity. Exenatide long-acting release (LAR) is formulated with exenatide and poly(D,L lactic-co-glycolic acid) microspheres (yellow circles), biodegradable medical polymers commonly used in extended drug release formulation.

$\mathrm{HbA}_{1 \mathrm{c}}$ of $\leq 7 \%$; and progressive weight loss was noted with a net-loss of $5.3 \mathrm{~kg}$ at the end of three years (Table 1). ${ }^{46}$

The efficacy of exenatide (10 $\mu \mathrm{g}$ twice daily) added to rosiglitazone ( $\geq 4 \mathrm{mg} / \mathrm{day}$ ) alone or pioglitazone ( $\geq 30 \mathrm{mg} /$ day) alone, or in combination with metformin was examined in a randomized, double-blind, placebocontrolled trial for 16 weeks (Table 1). When compared to placebo, addition of exenatide to thiazolidinediones (TZD) in the presence or absence of metformin reduced $\mathrm{HbA}_{1 \mathrm{c}}$ by $0.9 \%$, mean fasting plasma glucose by $1.6 \mathrm{mmol} / \mathrm{L}$, and body weight by $1.8 \mathrm{~kg}$. However, only $71 \%$ of subjects given exenatide as compared with $86 \%$ of subjects in the placebo group completed the study where many (14\%) discontinued the study because of gastrointestinal symptoms from exenatide. ${ }^{47}$

Exenatide therapy was also compared to insulin therapy as add-on to oral hypoglycemic agents. In a 26-week multicenter, open-label, randomized, controlled trial, subjects with T2DM whose glycemia was not adequately controlled by metformin and/or sulfonylurea were randomized to either adding exenatide $10 \mu \mathrm{g}$ twice daily or insulin glargine daily (titrating to fasting blood glucose of $<5.6 \mathrm{mmol} / \mathrm{L}$ ). At the end of 26 weeks, both groups achieved similar improvement in glycemic control $\left(1.1 \%\right.$ reduction in $\left.\mathrm{HbA}_{1 \mathrm{c}}\right)$. However, the exenatide group had better post-prandial glucose control while the glargine group had lower fasting plasma glucose levels. An average weight loss of $2.3 \mathrm{~kg}$ was noted with exenatide, and an average weight gain of $1.8 \mathrm{~kg}$ was noted with glargine. The drop out rate was $19.4 \%$ with exenatide (6\% due to nausea) and $9.7 \%$ with glargine. ${ }^{48}$

Exenatide was also compared to biphasic insulin aspart (30\% rapid-acting insulin aspart) in a 52-week, randomized, open-label trial in patients with T2DM whose glycemia was not optimally controlled with metformin and sulfonylurea. ${ }^{49}$ The efficacy of exenatide was comparable to biphasic insulin aspart with similar reduction in $\mathrm{HbA}_{1 \mathrm{c}}(1 \%$ versus $0.9 \%)$ and comparable reduction in fasting plasma glucose ( 1.8 versus $1.7 \mathrm{mmol} / \mathrm{L}$ ). The exenatide group had weight reduction of 


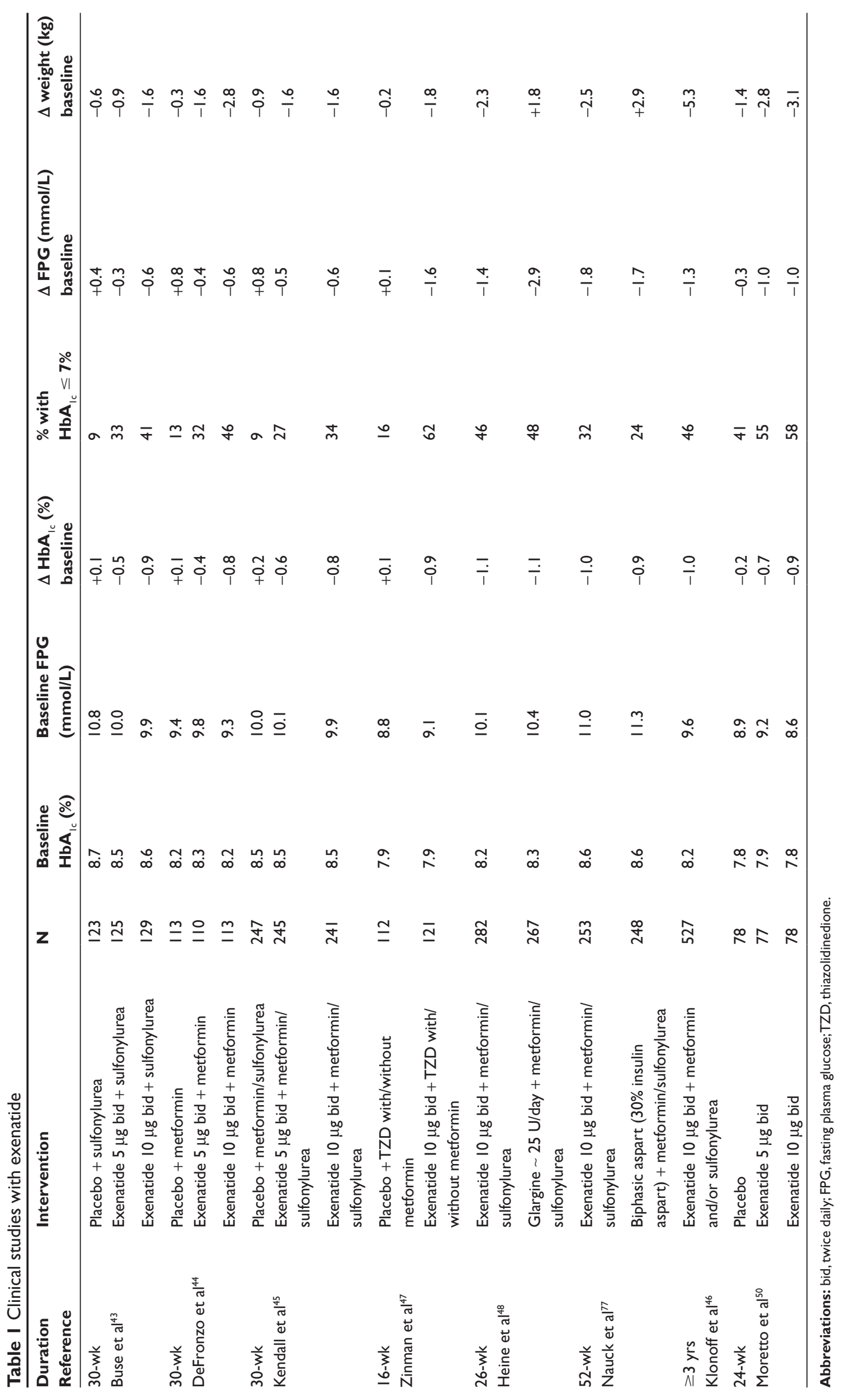


$2.5 \mathrm{~kg}$ while the biphasic insulin group had a weight increase of $2.9 \mathrm{~kg}$.

In a 24-week, randomized, double-blind, placebocontrolled, parallel-group study, patients with T2DM naïve to hypoglycemic agents and not optimally controlled with diet and exercise, were randomized to exenatide $5 \mu \mathrm{g}$ twice daily, exenatide $10 \mu \mathrm{g}$ twice daily, or placebo twice daily. Significant reductions in $\mathrm{HbA}_{1 \mathrm{c}}$ of $0.7 \%$ and $0.9 \%$ were noted in the exenatide $5 \mu \mathrm{g}$ and $10 \mu \mathrm{g}$ twice daily groups, respectively, compared to reduction of $0.2 \%$ in the placebo group. A similar significant reduction in fasting serum glucose of $1.0 \mathrm{mmol} / \mathrm{L}$ was noted in the exenatide $5 \mu \mathrm{g}$ and $10 \mu \mathrm{g}$ twice daily groups, respectively, compared to a reduction of $0.3 \mathrm{mmol} / \mathrm{L}$ in the placebo group. Significant reduction in weight was also observed in the exenatide $5 \mu \mathrm{g}$ and $10 \mu \mathrm{g}$ twice daily groups; $2.8 \mathrm{~kg}$ and $3.1 \mathrm{~kg}$, respectively, compared to $1.4 \mathrm{~kg}$ reduction in the placebo group..$^{50}$ The indication of using exenatide as monotherapy is currently under review by the United States Food and Drug Administration (FDA). ${ }^{51}$

\section{Safety and tolerability}

A meta-analysis based on randomized controlled trials was conducted to evaluate the safety and efficacy of incretin therapy in T2DM. ${ }^{52}$ The results from this analysis showed that the most common side effects of exenatide were nausea $(57 \%)$ and vomiting (17\%). The amount of nausea and vomiting was dose-dependent, usually mild to moderate in nature, lessened with dose titration, and most common during the initial weeks of therapy with a decline thereafter. Overall, $4 \%$ of patients withdrew from the studies because of gastrointestinal side effects. ${ }^{52}$ In addition, severe hypoglycemia associated with exenatide use was rare, reported in only five of 2781 patients in which all five patients also received a sulfonylurea. Mild to moderate hypoglycemia was noted in $16 \%$ of patients treated with exenatide versus $7 \%$ treated with placebo, and was again mostly occurred during co-administration with a sulfonylurea. Anti-exenatide antibodies were detected in $41 \%-49 \%$ of patients in the treatment arms but were not associated with glycemic control. ${ }^{43-45}$

The most serious (but rare) potential adverse event of exenatide is pancreatitis. In May 2008, the United Kingdom Medicines and Healthcare Products Regulatory Agency (MHRA) noted 89 post-marketing cases of pancreatitis with 87 of them occurring in the United States. ${ }^{53}$ In August 2008, the United States FDA reported six cases of hemorrhagic or necrotizing pancreatitis in exenatide-treated patients, and two of these patients died. In the exenatide clinical trials, the incident rate of pancreatitis was $1.79 / 1000$ subject years for exenatide-treated patients, 1.35 for insulin comparator group, and 2.72 for placebo-treated patients. ${ }^{53}$ The company that markets exenatide also tabulated incident data for pancreatitis in patients with T2DM (from insurance claims database) and noted a three- to four-fold greater incidence of acute pancreatitis in subjects with T2DM compared to patients without diabetes. ${ }^{53}$ While no definite relationship has been established between exenatide and pancreatitis, the FDA has requested that information about acute pancreatitis be included in the precautions section. ${ }^{53}$

\section{Exenatide and human $\beta$-cell function}

Similar to GLP-1, short-term infusion of exenatide (5 hrs) has been shown to improve first- and second-phase insulin secretion in patients with T2DM. ${ }^{54}$ Thirty weeks of exenatide use also resulted in improved $\beta$-cell function based on mathematical modeling of $\beta$ cell in response to test meal in patients with T2DM who were treated with metformin and/ or sulfonylurea. ${ }^{55}$ Furthermore, when compared to insulin glargine, exenatide treatment for 52 weeks significantly improved $\beta$-cell function as assessed by arginine-stimulated hyperglycemic clamp, and the $\beta$-cell function reverted to pretreatment levels after discontinuation of exenatide therapy. ${ }^{56}$

\section{Liraglutide}

Liraglutide is a GLP-1 analog with two modifications: a substitution of $\mathrm{Arg}^{34}$ for $\mathrm{Lys}^{34}$ and an attachment of a C-16 free-fatty acid derivative via a glutamoyl spacer to Lys $^{26}$ (Figure 1). The free-fatty acid derivative is thought to promote noncovalent binding of liraglutide to albumin; therefore, the absorption rate of liraglutide is delayed from the injection site and the rate of renal clearance of liraglutide is also slowed. ${ }^{57}$

\section{Pharmacology}

Like GLP-1 and exenatide, liraglutide must be injected subcutaneously. Peak plasma concentrations are detected 10-14 hrs after injection, and the half-life is about $11-13$ hrs. $^{58,59}$

\section{Efficacy studies}

The LEAD ${ }^{\circledR}$ programme (Liraglutide Effect and Action in Diabetes) is the Phase 3 clinical trial of liraglutide involving five randomized, controlled, double-blind studies that included about 4,000 patients with T2DM. Results from two of the studies have recently been published in peer-reviewed journals and the results from two other studies have been presented at a scientific meeting. 
The LEAD-3 Mono study is a double-blind, double-dummy, active-controlled, parallel-group study in which 746 patients with T2DM (previously treated with diet or oral hypoglycemic agent monotherapy) were randomized to receive liraglutide $1.2 \mathrm{mg}$, liraglutide $1.8 \mathrm{mg}$, or glimepiride $8 \mathrm{mg}$ once daily (Table 2).${ }^{60}$ Patients on oral hypoglycemic agent monotherapy had their treatment discontinued at randomization. At the end of 52 weeks, a significant reduction in $\mathrm{HbA}_{1 \mathrm{c}}$ was observed in all groups: $0.5 \%$ with glimepiride, $0.8 \%$ with liraglutide $1.2 \mathrm{mg}$, and $1.1 \%$ with liraglutide $1.8 \mathrm{mg}$. Significant reduction in fasting plasma glucose was also observed with an average reduction of $0.3 \mathrm{mmol} / \mathrm{L}, 0.8 \mathrm{mmol} / \mathrm{L}$, and $1.4 \mathrm{mmol} / \mathrm{L}$ in the glimepiride $8 \mathrm{mg}$, liraglutide $1.2 \mathrm{mg}$, and liraglutide $1.8 \mathrm{mg}$ groups, respectively. Furthermore, the percentage of patients who achieved a $\mathrm{HbA}_{1 \mathrm{c}}$ of less than $7 \%$ was $28 \%, 43 \%$, and $51 \%$ in the glimepiride $8 \mathrm{mg}$, liraglutide $1.2 \mathrm{mg}$, and liraglutide $1.8 \mathrm{mg}$ groups, respectively. Patients on liraglutide also lost weight of about $1.9 \mathrm{~kg}$ and $2.3 \mathrm{~kg}$ in the liraglutide $1.2 \mathrm{mg}$ and $1.8 \mathrm{mg}$ groups, respectively, while those on glimepiride $8 \mathrm{mg}$ gained about $1.2 \mathrm{~kg} .{ }^{60}$

The LEAD-2 study is a 26 -week, double-blind, doubledummy, placebo- and active-controlled, parallel-group clinical trial in which 1091 patients with T2DM were randomized to liraglutide once daily (either $0.6 \mathrm{mg}, 1.2 \mathrm{mg}$, or $1.8 \mathrm{mg}$ ), glimepiride $4 \mathrm{mg}$ once daily, or placebo, all in combination with metformin (1 gm twice daily) (Table 2) ${ }^{61}$ All other oral hypoglycemic agents were discontinued at randomization. After 26 weeks, $\mathrm{HbA}_{1 \mathrm{c}}$ was reduced by $1.0 \%$ in the liraglutide $1.2 \mathrm{mg} / \mathrm{metformin}$, the liraglutide $1.8 \mathrm{mg} / \mathrm{metformin}$, and the glimepiride/metformin groups; decreased by $0.7 \%$ in the liraglutide $0.6 \mathrm{mg} / \mathrm{metformin}$ group; and increased by $0.1 \%$ in the placebo/metformin group. The percentage of participants who achieved $\mathrm{HbA}_{1 \mathrm{c}}$ of less than $7 \%$ was $28 \%, 35 \%$, and $42 \%$ for the liraglutide/metformin groups $(0.6 \mathrm{mg}, 1.2 \mathrm{mg}$, $1.8 \mathrm{mg}$, respectively), $36 \%$ for the glimepiride/metformin group, and $11 \%$ for the placebo/metformin group. Fasting plasma glucose was decreased by $1.1 \mathrm{mmol} / \mathrm{L}, 1.6 \mathrm{mmol} / \mathrm{L}$, $1.7 \mathrm{mmol} / \mathrm{L}$ in the liraglutide/metformin groups $(0.6,1.2$, and $1.8 \mathrm{mg}$ of liraglutide, respectively) compared to a reduction of $1.3 \mathrm{mmol} / \mathrm{L}$ in the glimepiride/metformin group and an increase of $0.4 \mathrm{mmol} / \mathrm{L}$ in the placebo/metformin group. Weight loss was also noted in the liraglutide/metformin groups in a dose-dependent fashion; weight reduction of $1.8 \mathrm{~kg}, 2.6 \mathrm{~kg}$, and $2.8 \mathrm{~kg}$ for the liraglutide/metformin groups (liraglutide $0.6 \mathrm{mg}, 1.2 \mathrm{mg}$, and $1.8 \mathrm{mg}$, respectively), which was significantly greater than the $1.5 \mathrm{~kg}$ weight loss noted in the placebo/metformin group. The glimepiride/metformin group had a $1.0 \mathrm{~kg}$ weight gain. ${ }^{61}$
In another 26-week, randomized, double-dummy, placebo-controlled study, 1041 subjects were randomized to five different arms: liraglutide $(0.6 \mathrm{mg}, 1.2 \mathrm{mg}$, or $1.8 \mathrm{mg})$ once daily added to glimepiride once daily, placebo/glimepiride 2-4 mg daily, or rosiglitazone $4 \mathrm{mg} / \mathrm{glimepiride}$ combination once daily (Table 2). ${ }^{62} \mathrm{HbA}_{1 \mathrm{c}}$ reduction of $0.6 \%, 1.1 \%$, and $1.1 \%$, were seen in the liraglutide $(0.6 \mathrm{mg}, 1.2 \mathrm{mg}, 1.8 \mathrm{mg}) /$ glimepiride groups, respectively. $\mathrm{An}_{\mathrm{HbA}}$ reduction of $0.4 \%$ was noted in the rosiglitazone/glimepiride group, and a $0.2 \%$ $\mathrm{HbA}_{1 \mathrm{c}}$ increase was noted in the placebo/glimepiride group. The percentage of participants who achieved $\mathrm{HbA}_{1 \mathrm{c}}$ of less than $7 \%$ was $24 \%, 35 \%$, and $42 \%$ in the liraglutide $(0.6 \mathrm{mg}$, $1.2 \mathrm{mg}$, and $1.8 \mathrm{mg}$ )/glimepiride groups, respectively, $8 \%$ in the placebo/glimepiride group, and $22 \%$ in the rosiglitazone/ glimepiride group. Weight gain of $0.7 \mathrm{~kg}, 0.3 \mathrm{~kg}$, and $2.1 \mathrm{~kg}$ was noted in the liraglutide $0.6 \mathrm{mg} /$ glimepiride, liraglutide $1.2 \mathrm{mg} /$ glimepiride, and the rosiglitazone/glimepiride groups, respectively, while a weight reduction of $0.2 \mathrm{~kg}$ and $0.1 \mathrm{~kg}$ was noted in the liraglutide $1.8 \mathrm{mg} / \mathrm{glimepiride}$ group and the placebo/glimepiride group, respectively. Fasting plasma glucose was reduced by $0.7 \mathrm{mmol} / \mathrm{L}, 1.6 \mathrm{mmol} / \mathrm{L}$, $1.6 \mathrm{mmol} / \mathrm{L}$ in the liraglutide $(0.6 \mathrm{mg}, 1.2 \mathrm{mg}, 1.8 \mathrm{mg}) /$ glimepiride groups, respectively, reduced by $0.9 \mathrm{mmol} / \mathrm{L}$ in the rosiglitazone/glimepiride group, and increased by $1.0 \mathrm{mmol} / \mathrm{L}$ in the placebo/glimepiride group. ${ }^{62}$

In another 26-week randomized clinical trial, 581 subjects with T2DM were randomized to $1.8 \mathrm{mg}$ liraglutide, placebo, or insulin glargine (open label) once daily as add-on to metformin $1 \mathrm{gm}$ twice daily plus glimepiride $2-4 \mathrm{mg}$ once daily (Table 2 ) ${ }^{63}$ $\mathrm{HbA}_{1 \mathrm{c}}$ reduction of $1.3 \%, 0.2 \%$, and $1.1 \%$ was noted in the liraglutide/metformin/glimepiride, placebo/metformin/ glimepiride, and glargine/metformin/glimepiride groups, respectively. Fasting plasma glucose reduction of $1.6 \mathrm{mmol} / \mathrm{L}$ and $1.8 \mathrm{mmol} / \mathrm{L}$ were noted in the liraglutide/metformin/ glimepiride and glargine/metformin/glimepiride groups while an increased of $0.5 \mathrm{mmol} / \mathrm{L}$ was noted in the placebo/metformin/ glimepiride group. Furthermore, weight reduction of $1.8 \mathrm{~kg}$, $0.4 \mathrm{~kg}$ was noted in the liraglutide/metformin/glimepiride and placebo/metformin/glimepiride groups, and weight increased of $1.6 \mathrm{~kg}$ was reported in the glargine/metformin/glimepiride group. The percentage of subjects who achieved $\mathrm{HbA}_{1 \mathrm{c}}$ of less than $6.5 \%$ was $37 \%, 11 \%$, and $24 \%$ in the liraglutide/ metformin/glimepiride, placebo/metformin/glimepiride, and glargine/metformin/glimepiride groups, respectively. ${ }^{63}$

\section{Safety and tolerability}

Similar to exenatide, the most frequently report adverse events for liraglutide were nausea and vomiting, especially 


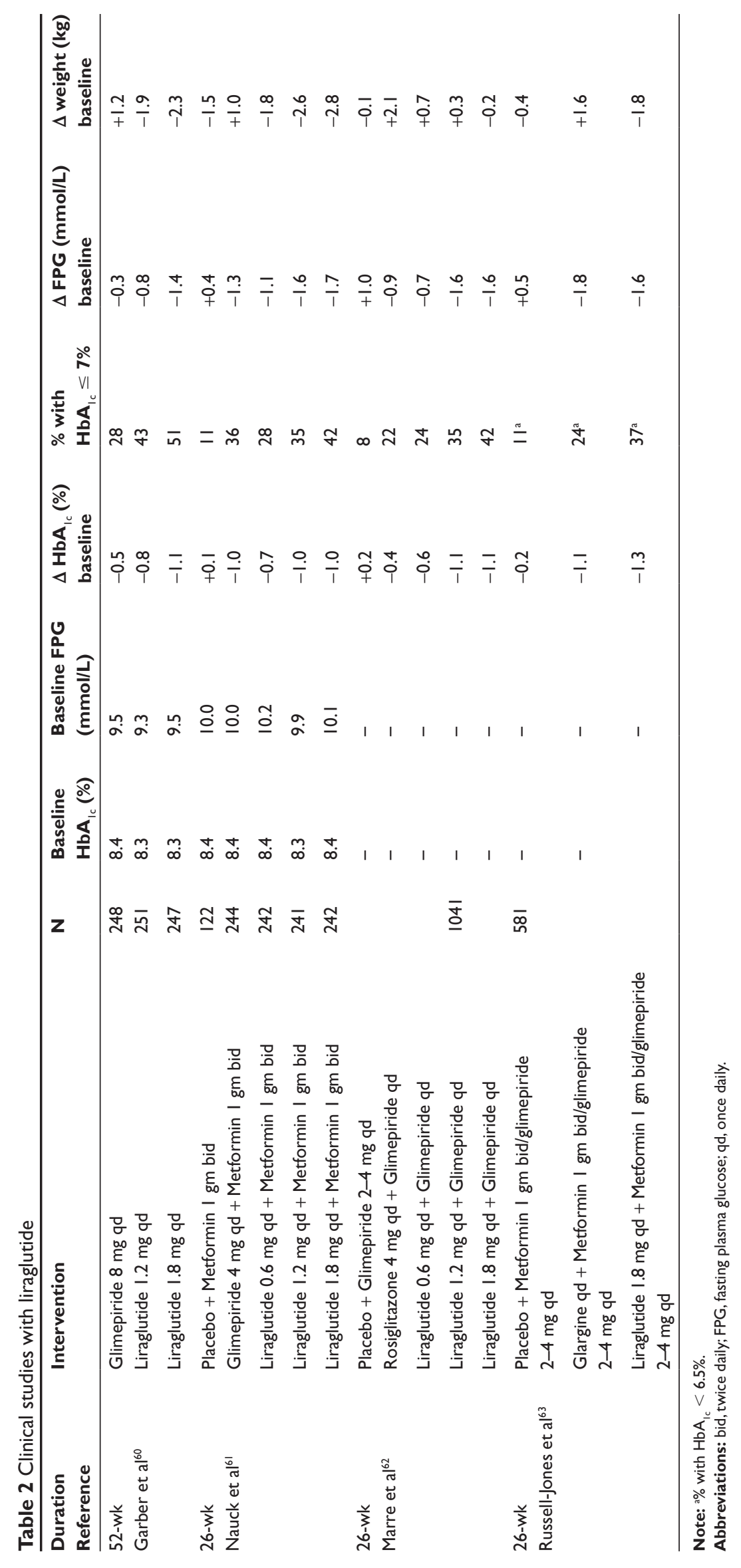


at the higher doses. ${ }^{52}$ In the LEAD-2 study, hypoglycemia was noted in 3\% of the liraglutide/metformin and placebo/ metformin groups compared to $17 \%$ in the glimepiride/ metformin group. Nausea was reported to occur in 11\%-19\% of the liraglutide/metformin groups in a dose-dependent fashion compared to $3 \%-4 \%$ in the placebo/metformin and glimepiride/metformin groups. Nausea was noted to decrease over the duration of the study. There were two cases of pancreatitis reported, one in the liraglutide $1.2 \mathrm{mg}$ group and one in the glimepiride group, and both recovered ${ }^{61}$ In the LEAD-3 study, $12 \%$ and $8 \%$ of the liraglutide groups (1.2 $\mathrm{mg}$ and $1.8 \mathrm{mg}$, respectively) versus $24 \%$ of the glimepiride group suffered mild hypoglycemia. Nausea was reported in $28 \%$ and $29 \%$ of the subjects in the liraglutide groups (1.2 $\mathrm{mg}$ and $1.8 \mathrm{mg}$, respectively), and $9 \%$ of the glimepiride group. Again, the incidence of nausea decreased over time. Two participants, one each in the $1.2 \mathrm{mg}$ and $1.8 \mathrm{mg}$ liraglutide groups, developed pancreatitis during the study and both recovered.$^{60}$ In one of the 26 -week studies, $9 \%-13 \%$ of the liraglutide treated subjects developed antibodies to liraglutide. Nausea was reported in 5\%-11\% of the liraglutide/glimepiride groups, $2 \%$ of the placebo/glimepiride group, and $3 \%$ of the rosiglitzaone/glimepiride. ${ }^{62}$ In another 26 -week study, $10 \%$ of the subjects in the liraglutide group developed liraglutide antibodies. ${ }^{63}$ Nausea was reported in $14 \%, 4 \%$, and $1 \%$ of the subjects in the liraglutide/metformin/glimepiride, placebo/ metformin/glimepiride, and glargine/metformin/glimepiride groups. ${ }^{63}$ Hypoglycemia was reported in $27 \%, 17 \%$, and $29 \%$ of the subjects in the liraglutide/metformin/glimepiride, placebo/metformin/glimepiride, and glargine/metformin/ glimepiride groups. ${ }^{63}$

\section{Liraglutide and human $\beta$ cell function}

In patients with T2DM, a single dose of liraglutide was able to improve $\beta$-cell sensitivity to glucose ${ }^{64}$ Two different studies have demonstrated that treatment of patients with T2DM with liraglutide for seven days improved $\beta$-cell function as assessed by a model using multiple-meal tests, arginine stimulation test, and hyperglycemic clamp. ${ }^{65,66}$

\section{Exenatide long-acting release (LAR)}

Exenatide LAR is formulated with exenatide and poly (D,L lactic-co-glycolic acid) microspheres, a biodegradable medical polymer commonly used in extended drug release formulation. ${ }^{67}$ Once weekly subcutaneous injection is thought to be the desired frequency, and it is currently undergoing phase 3 clinical trials.

\section{Pharmacology}

With a weekly injection of $2 \mathrm{mg}$ exenatide LAR, a therapeutic plasma level of $50 \mathrm{pg} / \mathrm{mL}$ was reached after the second injection. The steady state concentration of exenatide LAR ( $232 \mathrm{pg} / \mathrm{mL}$ ) was reached by week 6 . This level is similar to the peak level reached by a single injection of $10 \mu \mathrm{g}$ of exenatide. After 15 weeks of treatment with exenatide LAR, no more injections were given, and its concentration gradually decreased to below therapeutic level by week $21{ }^{68}$

\section{Efficacy studies}

In a randomized, placebo-controlled, phase 2 study, 45 patients with T2DM sub-optimally controlled by metformin and/or diet and exercise were randomized to exenatide LAR $0.8 \mathrm{mg}$, exenatide LAR $2.0 \mathrm{mg}$, or placebo LAR once weekly for 15 weeks (Table 3 ). ${ }^{68}$ Subjects who were on metformin continued at the same dose. Exenatide LAR reduced $\mathrm{HbA}_{1 \mathrm{c}}$ by $1.4 \%$ and $1.7 \%$ in the exenatide LAR $0.8 \mathrm{mg}$ and $2.0 \mathrm{mg}$ groups, respectively, compared to an increase of $0.4 \%$ in the placebo group. The percentage of subjects who achieved $\mathrm{HbA}_{1 \mathrm{c}}$ of less than $7 \%$ was $36 \%$ and $86 \%$ for the exenatide LAR $0.8 \mathrm{mg}$ and $2.0 \mathrm{mg}$ groups, respectively, and no change in $\mathrm{HbA}_{1 \mathrm{c}}$ was noted for the placebo group. Fasting plasma glucose was reduced by $2.4 \mathrm{mmol} / \mathrm{L}$ and $2.2 \mathrm{mmol} / \mathrm{L}$ in the exenatide LAR $0.8 \mathrm{mg}$ and $2.0 \mathrm{mg}$ groups, respectively, compared to an increase of $1.0 \mathrm{mmol} / \mathrm{L}$ in the placebo group. Subjects in the exenatide LAR $2.0 \mathrm{mg}$ group lost an average weight of $3.8 \mathrm{~kg}$ while those in the exenatide LAR $0.8 \mathrm{mg}$ and placebo groups did not have any change in weight. ${ }^{68}$

In a 30-week, randomized, open-label, comparatorcontrolled, noninferiority study, exenatide LAR $2 \mathrm{mg}$ once weekly was compared to exenatide $10 \mu \mathrm{g}$ twice daily in 295 patients with T2DM treated by diet, metformin, sulfonylurea, thiazolidinedione, or any combination of the two agents (Table 3). ${ }^{67}$ Patients on exenatide LAR has $\mathrm{HbA}_{1 \mathrm{c}}$ reduction of $1.9 \%$ compared to $1.5 \%$ reduction in the exenatide twice daily group. Furthermore, $77 \%$ of the subjects in the exenatide LAR group achieved $\mathrm{HbA}_{1 \mathrm{c}}$ of less than $7 \%$ compared to $61 \%$ of the exenatide twice daily group. Weight reduction was comparable in that subjects in the exenatide LAR group lost $3.7 \mathrm{~kg}$ while subjects given exenatide twice daily lost $3.6 \mathrm{~kg}$ of weight. Fasting plasma glucose was also significantly reduced by $2.3 \mathrm{mmol} / \mathrm{L}$ in the exenatide LAR group compared to $1.4 \mathrm{mmol} / \mathrm{L}$ in the exenatide twice daily group. Fasting plasma glucagon levels were also significantly lower in the exenatide LAR-treated group compared to the placebo group. ${ }^{67}$ 


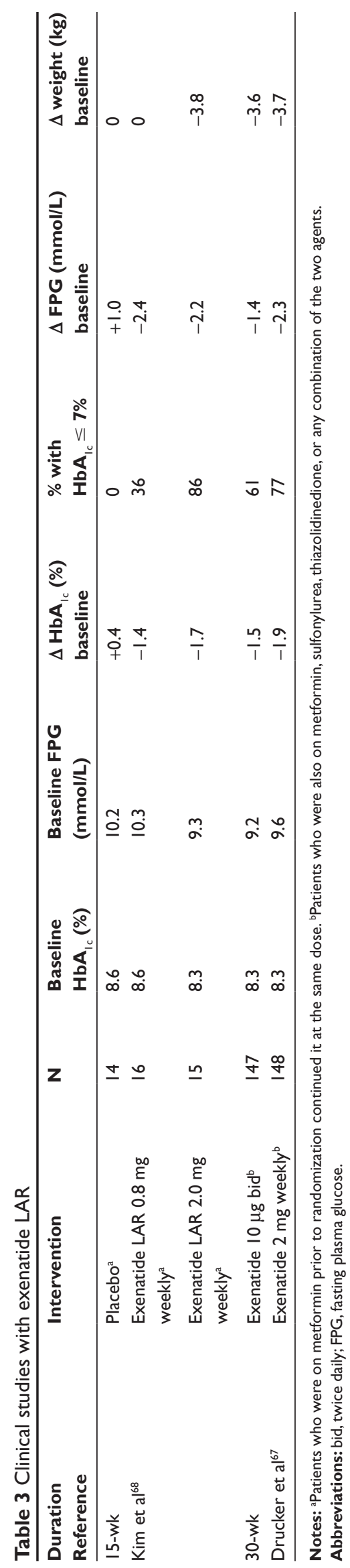

\section{Safety and tolerability}

In the phase 2 study, $19 \%$ and $27 \%$ of the exenatide LAR $0.8 \mathrm{mg}$ and $2.0 \mathrm{mg}$ groups, respectively, experienced nausea compared to $15 \%$ in the placebo group. ${ }^{68}$ Twenty-five percent of the subjects in the exenatide LAR $0.8 \mathrm{mg}$ group experienced hypoglycemia with only one case confirmed by blood glucose concentration $(3.1 \mathrm{mmol} / \mathrm{L})$, while the exenatide LAR $2.0 \mathrm{mg}$ and placebo groups did not report any hypoglycemia. ${ }^{6}$ Sixty-seven percent of the subjects in the exenatide LAR groups developed positive anti-exenatide antibodies after 15 weeks. ${ }^{68}$ In the 30 -week randomized trial, anti-exenatide antibody levels were higher with exenatide LAR versus the exenatide twice daily group. ${ }^{67}$ The antibody titers seems to declined progressively after 16 weeks of treatment. ${ }^{67}$ Nausea was reported in $26 \%$ of the exenatide LAR group compared to $35 \%$ of the exenatide twice daily group, while vomiting was reported in $11 \%$ of the exenatide LAR group compared to $19 \%$ of the exenatide twice daily group. Injection site pruritus was also much more frequent (18\%) in the exenatide LAR group compared to the exenatide twice daily group $(1 \%) \cdot{ }^{67}$ No cases of pancreatitis were reported in either of the studies involving exenatide and exenatide LAR. ${ }^{67}$

\section{Other GLP-IR agonists under development}

There are other GLP-1R agonists currently under clinical development that are anticipated to have longer half-lives and presumably less gastrointestinal side effects. LY2189265 is a GLP-1 analog-Fc fusion protein, and LY2428757 is a pegylated GLP-1 analog, both can be administered just once weekly ${ }^{69}$ CJC-1134-PC is a recombinant human serum albumin-exendin- 4 conjugated protein that has a half-life of approximately eight days and Albiglutide is an albuminGLP-1 protein complex, both can be administered once weekly. ${ }^{70-72}$ NN9535 is another long-acting human GLP-1 analog designed for once weekly injection using proteinacylation technology. ${ }^{73}$ Taspoglutide and AVE0010 are two other GLP-1R agonists currently undergoing clinical trials. ${ }^{74,75}$ An oral formulation of a GLP-1R agonist is reportedly also under development. ${ }^{76}$ The compounds mentioned here are just a few representations of the GLP-1R agonists under clinical development, and are by no means comprehensive. Few data are publically available regarding these compounds.

\section{Conclusions}

GLP-1R agonists are a new class of hypoglycemic agents that have generated a lot of interests in the field of diabetes. 
The development of GLP-1R agonists started with their potential as insulin secretagogues. Exogenous administration of GLP-1 and GLP-1R agonists at pharmacological doses showed that they not only have insulinotropic effect, but also effects on suppressing glucagon secretion in the presence of hyperglycemia, delaying post-prandial gastric emptying, inducing satiety, and promoting weight loss over prolonged administration-all of which work in synergy to normalize glucose homeostasis in patients with T2DM. Furthermore, GLP-1R agonists were noted to increase insulin synthesis, increase islet cell turnover, and decrease $\beta$ cell apoptosis in animals-properties that may help slow the progression or even reverse the course of diabetes. Indirect measures of $\beta$-cell function showed that GLP-1R agonists improved $\beta$-cell responsiveness to glucose as well as first- and second-phase insulin secretion. However, the improvement in $\beta$-cell functions reverted back to pre-treatment levels after discontinuation of therapy, at least in the case of exenatide. Nausea and vomiting are the common side effects during the initial weeks of therapy, which lessen with dose titration, and generally decline with continuous use. Patients with severe gastrointestinal diseases probably should not be started on GLP-1R agonists in case of development of pancreatitis. Long-term use of exenatide (data available up to three years) has shown sustained $\mathrm{HbA}_{1 \mathrm{c}}$ reduction and weight loss, which are very encouraging because these effects have not been shown by any other class of hypoglycemic agents. GLP-1R agonists as treatment modalities for diabetes have a promising future, especially with their potential to help reverse or prevent diabetes.

\section{Acknowledgments}

The writing of this manuscript was supported entirely by the Intramural Research Program of the NIH, National Institute on Aging. The views expressed in this manuscript are those of the authors and do not reflect those of the NIH. The authors report no conflicts of interest in this work.

\section{References}

1. Elrick H, Stimmler L, Hlad CJ, Jr, Arai Y. Plasma insulin response to oral and intravenous glucose administration. J Clin Endocrinol Metab. 1964;24:1076-1082.

2. McIntyre N, Holdsworth CD, Turner DS. Intestinal factors in the control of insulin secretion. J Clin Endocrinol Metab. 1965;25(10): 1317-1324.

3. Perley MJ, Kipnis DM. Plasma insulin responses to oral and intravenous glucose: studies in normal and diabetic sujbjects. J Clin Invest. 1967;46(12):1954-1962.

4. Buffa R, Polak JM, Pearse AGE, Solcia E, Grimelius L, Capella C. Identification of the Intestinal Cell Storing Gastric Inhibitory Peptide. Histochemistry. 1975;43:249-255.
5. Orskov C, Holst JJ, Knuhtsen S, Baldissera FG, Poulsen SS, Nielsen OV. Glucagon-like peptides GLP-1 and GLP-2, predicted products of the glucagon gene, are secreted separately from pig small intestine but not pancreas. Endocrinology. 1986;119(4):1467-1475.

6. Theodorakis MJ, Carlson O, Michopoulos S, et al. Human duodenal enteroendocrine cells: source of both incretin peptides, GLP-1 and GIP. Am J Physiol Endocrinol Metab. 2006;290(3):E550-E559.

7. Eissele R, Goke R, Willemer S, et al. Glucagon-like peptide- 1 cells in the gastrointestinal tract and pancreas of rat, pig and man. Eur J Clin Invest. 1992;22(4):283-291.

8. Meier JJ, Nauck MA. Glucagon-like peptide 1(GLP-1) in biology and pathology. Diabetes Metab Res Rev. 2005;21(2):91-117.

9. Krarup T, Saurbrey N, Moody AJ, Kuhl C, Madsbad S. Effect of porcine gastric inhibitory polypeptide on beta-cell function in type I and type II diabetes mellitus. Metabolism. 1987;36(7):677-682.

10. Nauck MA, Heimesaat MM, Orskov C, Holst JJ, Ebert R, Creutzfeldt W. Preserved incretin activity of glucagon-like peptide 1 [7-36 amide] but not of synthetic human gastric inhibitory polypeptide in patients with type-2 diabetes mellitus. J Clin Invest. 1993;91(1):301-307.

11. Elahi D, McAloon-Dyke M, Fukagawa NK, et al. The insulinotropic actions of glucose-dependent insulinotropic polypeptide (GIP) and glucagon-like peptide-1 (7-37) in normal and diabetic subjects. Regul Pept. 14 1994;51(1):63-74.

12. Feinle C, Chapman IM, Wishart J, Horowitz M. Plasma glucagon-like peptide-1 (GLP-1) responses to duodenal fat and glucose infusions in lean and obese men. Peptides. 2002;23(8):1491-1495.

13. Jang HJ, Kokrashvili Z, Theodorakis MJ, et al. Gut-expressed gustducin and taste receptors regulate secretion of glucagon-like peptide-1. Proc Natl Acad Sci U S A. 2007;104(38):15069-15074.

14. Elliott RM, Morgan LM, Tredger JA, Deacon S, Wright J, Marks V. Glucagon-like peptide-1 (7-36)amide and glucose-dependent insulinotropic polypeptide secretion in response to nutrient ingestion in man: acute post-prandial and 24-h secretion patterns. J Endocrinol. 1993;138(1):159-166.

15. Kim W, Egan JM. The role of incretins in glucose homeostasis and diabetes treatment. Pharmacol Rev. 2008;60(4):470-512.

16. Vollmer K, Holst JJ, Baller B, et al. Predictors of incretin concentrations in subjects with normal, impaired, and diabetic glucose tolerance. Diabetes. 2008;57(3):678-687.

17. Nauck MA, Heimesaat MM, Behle K, et al. Effects of glucagon-like peptide 1 on counterregulatory hormone responses, cognitive functions, and insulin secretion during hyperinsulinemic, stepped hypoglycemic clamp experiments in healthy volunteers. J Clin Endocrinol Metab. 2002;87(3):1239-1246.

18. Toft-Nielsen MB, Damholt MB, Madsbad S, et al. Determinants of the impaired secretion of glucagon-like peptide-1 in type 2 diabetic patients. J Clin Endocrinol Metab. 2001;86(8):3717-3723.

19. Vilsboll T, Krarup T, Deacon CF, Madsbad S, Holst JJ. Reduced postprandial concentrations of intact biologically active glucagon-like peptide 1 in type 2 diabetic patients. Diabetes. 2001;50(3):609-613.

20. Kieffer TJ, McIntosh CH, Pederson RA. Degradation of glucosedependent insulinotropic polypeptide and truncated glucagon-like peptide 1 in vitro and in vivo by dipeptidyl peptidase IV. Endocrinology. $1995 ; 136(8): 3585-3596$.

21. Hupe-Sodmann K, McGregor GP, Bridenbaugh R, et al. Characterisation of the processing by human neutral endopeptidase 24.11 of GLP-1 (7-36) amide and comparison of the substrate specificity of the enzyme for other glucagon-like peptides. Regul Pept. 1995;58(3):149-156.

22. Meier JJ, Nauck MA, Kranz D, et al. Secretion, degradation, and elimination of glucagon-like peptide 1 and gastric inhibitory polypeptide in patients with chronic renal insufficiency and healthy control subjects. Diabetes. 2004;53(3):654-662.

23. Hansen L, Deacon CF, Orskov C, Holst JJ. Glucagon-like peptide-1-(7-36)amide is transformed to glucagon-like peptide1-(9-36)amide by dipeptidyl peptidase IV in the capillaries supplying the L cells of the porcine intestine. Endocrinology. 1999;140(11): 5356-5363. 
24. Ruiz-Grande C, Alarcon C, Alcantara A, et al. Renal catabolism of truncated glucagon-like peptide 1. Horm Metab Res. 1993;25(12):612-616.

25. Thorens B, Porret A, Buhler L, Deng SP, Morel P, Widmann C. Cloning and functional expression of the human islet GLP-1 receptor. Demonstration that exendin-4 is an agonist and exendin-(9-39) an antagonist of the receptor. Diabetes. 1993;42(11):1678-1682.

26. Kieffer TJ, Habener JF. The glucagon-like peptides. Endocr Rev. 1999;20(6):876-913.

27. Kjems LL, Holst JJ, Volund A, Madsbad S. The influence of GLP-1 on glucose-stimulated insulin secretion: effects on beta-cell sensitivity in type 2 and nondiabetic subjects. Diabetes. 2003;52(2):380-386.

28. Rachman J, Gribble FM, Barrow BA, Levy JC, Buchanan KD, Turner RC. Normalization of insulin responses to glucose by overnight infusion of glucagon-like peptide 1 (7-36) amide in patients with NIDDM. Diabetes. 1996;45(11):1524-1530.

29. Zander M, Madsbad S, Madsen JL, Holst JJ. Effect of 6-week course of glucagon-like peptide 1 on glycaemic control, insulin sensitivity, and beta-cell function in type 2 diabetes: a parallel-group study. Lancet. 2002;359(9309):824-830.

30. Meneilly GS, Greig N, Tildesley H, Habener JF, Egan JM, Elahi D. Effects of 3 months of continuous subcutaneous administration of glucagon-like peptide 1 in elderly patients with type 2 diabetes. Diabetes Care. 2003;26(10):2835-2841.

31. Meneilly GS, Veldhuis JD, Elahi D. Deconvolution analysis of rapid insulin pulses before and after six weeks of continuous subcutaneous administration of glucagon-like peptide-1 in elderly patients with type 2 diabetes. J Clin Endocrinol Metab. 2005;90(11):6251-6256.

32. Nauck MA, Kleine N, Orskov C, Holst JJ, Willms B, Creutzfeldt W. Normalization of fasting hyperglycaemia by exogenous glucagon-like peptide 1 (7-36 amide) in type 2 (non-insulin-dependent) diabetic patients. Diabetologia. 1993;36(8):741-744.

33. Meier JJ, Gallwitz B, Salmen S, et al. Normalization of glucose concentrations and deceleration of gastric emptying after solid meals during intravenous glucagon-like peptide 1 in patients with type 2 diabetes. J Clin Endocrinol Metab. 2003;88(6):2719-2725.

34. Verdich C, Flint A, Gutzwiller JP, et al. A meta-analysis of the effect of glucagon-like peptide-1 (7-36) amide on ad libitum energy intake in humans. J Clin Endocrinol Metab. 2001;86(9):4382-4389.

35. Naslund E, Gutniak M, Skogar S, Rossner S, Hellstrom PM. Glucagonlike peptide 1 increases the period of postprandial satiety and slows gastric emptying in obese men. Am J Clin Nutr. 1998;68(3):525-530.

36. Brubaker PL, Drucker DJ. Minireview: Glucagon-like peptides regulate cell proliferation and apoptosis in the pancreas, gut, and central nervous system. Endocrinology. 2004;145(6):2653-2659.

37. Egan JM, Bulotta A, Hui H, Perfetti R. GLP-1 receptor agonists are growth and differentiation factors for pancreatic islet beta cells. Diabetes Metab Res Rev. 2003;19(2):115-123.

38. Byrne MM, Gliem K, Wank U, et al. Glucagon-like peptide 1 improves the ability of the beta-cell to sense and respond to glucose in subjects with impaired glucose tolerance. Diabetes. 1998;47(8):1259-1265.

39. Migoya EM, Miller J, Larson P, et al. Sitagliptin, a selective DPP-4 inhibitor, and metformin have complementary effects to increase active GLP-1 concentrations. Diabetes. 2007;56(S1):A74.

40. Green BD, Gault VA, O'Harte FP, Flatt PR. Structurally modified analogues of glucagon-like peptide-1 (GLP-1) and glucose-dependent insulinotropic polypeptide (GIP) as future antidiabetic agents. Curr Pharm Des. 2004;10(29):3651-3662.

41. Kolterman OG, Kim DD, Shen L, et al. Pharmacokinetics, pharmacodynamics, and safety of exenatide in patients with type 2 diabetes mellitus. Am J Health Syst Pharm. 2005;62(2):173-181.

42. Simonsen L, Holst JJ, Deacon CF. Exendin-4, but not glucagon-like peptide-1, is cleared exclusively by glomerular filtration in anaesthetised pigs. Diabetologia. 2006;49(4):706-712.

43. Buse JB, Henry RR, Han J, Kim DD, Fineman MS, Baron AD. Effects of exenatide (exendin-4) on glycemic control over 30 weeks in sulfonylurea-treated patients with type 2 diabetes. Diabetes Care. 2004;27(11):2628-2635.
44. DeFronzo RA, Ratner RE, Han J, Kim DD, Fineman MS, Baron AD. Effects of exenatide (exendin-4) on glycemic control and weight over 30 weeks in metformin-treated patients with type 2 diabetes. Diabetes Care. 2005;28(5):1092-1100.

45. Kendall DM, Riddle MC, Rosenstock J, et al. Effects of exenatide (exendin-4) on glycemic control over 30 weeks in patients with type 2 diabetes treated with metformin and a sulfonylurea. Diabetes Care. 2005;28(5):1083-1091.

46. Klonoff DC, Buse JB, Nielsen LL, et al. Exenatide effects on diabetes, obesity, cardiovascular risk factors and hepatic biomarkers in patients with type 2 diabetes treated for at least 3 years. Curr Med Res Opin. 2008;24(1):275-286

47. Zinman B, Hoogwerf BJ, Duran Garcia S, et al. The effect of adding exenatide to a thiazolidinedione in suboptimally controlled type 2 diabetes: a randomized trial. Ann Intern Med. 2007;146(7):477-485.

48. Heine RJ, Van Gaal LF, Johns D, Mihm MJ, Widel MH, Brodows RG. Exenatide versus insulin glargine in patients with suboptimally controlled type 2 diabetes: a randomized trial. Ann Intern Med. 2005;143(8): 559-569.

49. Nauck MA, Meininger G, Sheng D, Terranella L, Stein PP. Efficacy and safety of the dipeptidyl peptidase-4 inhibitor, sitagliptin, compared with the sulfonylurea, glipizide, in patients with type 2 diabetes inadequately controlled on metformin alone: a randomized, double-blind, noninferiority trial. Diabetes Obes Metab. 2007;9(2):194-205.

50. Moretto TJ, Milton DR, Ridge TD, et al. Efficacy and tolerability of exenatide monotherapy over 24 weeks in antidiabetic drug-naive patients with type 2 diabetes: a randomized, double-blind, placebocontrolled, parallel-group study. Clin Ther. 2008;30(8):1448-1460.

51. Eli Lilly and Company. Amylin, Lilly Update on FDA Review of Byetta (exenatide) Injection Monotherapy Submission. 2008. Accessed February 17, 2009. Available from: http://newsroom.lilly. com/releasedetail.cfm?releaseid $=352884$.

52. Amori RE, Lau J, Pittas AG. Efficacy and safety of incretin therapy in type 2 diabetes: systematic review and meta-analysis. JAMA. 2007;298(2):194-206.

53. Bain SC, Stephens JW. Exenatide and pancreatitis: an update. Expert Opin Drug Saf. 2008;7(6):643-644.

54. Fehse F, Trautmann M, Holst JJ, et al. Exenatide augments firstand second-phase insulin secretion in response to intravenous glucose in subjects with type 2 diabetes. J Clin Endocrinol Metab. 2005;90(11):5991-5997.

55. Mari A, Nielsen LL, Nanayakkara N, DeFronzo RA, Ferrannini E, Halseth A. Mathematical modeling shows exenatide improved beta-cell function in patients with type 2 diabetes treated with metformin or metformin and a sulfonylurea. Horm Metab Res. 2006;38(12):838-844.

56. Bunck MC, Diamant M, Corner A, et al. One-year treatment with exenatide improves beta-cell function, compared to insulin glargine, in metformin treated type 2 diabetes patients: A randomized, controlled trial. Diabetes Care. 2009 Feb 5. [Epub ahead of print]

57. Knudsen LB, Knudsen SM, Wilken M, et al. Plasma protein binding of NN2211, a long-acting derivative of GLP-1, is important for its efficacy. Diabetes. 2003;52(Suppl 1):A321-A322.

58. Knudsen LB, Nielsen PF, Huusfeldt PO, et al. Potent derivatives of glucagon-like peptide-1 with pharmacokinetic properties suitable for once daily administration. J Med Chem. 2000;43(9):1664-1669.

59. Agerso H, Jensen LB, Elbrond B, Rolan P, Zdravkovic M. The pharmacokinetics, pharmacodynamics, safety and tolerability of NN2211, a new long-acting GLP-1 derivative, in healthy men. Diabetologia. 2002;45(2):195-202.

60. Garber A, Henry R, Ratner R, et al. Liraglutide versus glimepiride monotherapy for type 2 diabetes (LEAD-3 Mono): a randomised, 52-week, phase III, double-blind, parallel-treatment trial. Lancet. 2009;373(9662):473-481

61. Nauck M, Frid A, Hermansen K, et al. Efficacy and safety comparison of liraglutide, glimepiride, and placebo, all in combination with metformin, in type 2 diabetes: the LEAD (liraglutide effect and action in diabetes)2 study. Diabetes Care. 2009;32(1):84-90. 
62. Marre M, Shaw J, Brandle M, et al. Liraglutide, a once-daily human GLP-1 analog, added to a sulfonylurea (SU) offers significantly better glycemic control and favorable weight change compared with rosiglitazone and SU combination therapy in subjects with type 2 diabetes. Abstract presented at San Francisco, CA: American Diabetes Association 68th Scientific Sessions, 2008.

63. Russell-Jones D, Vaag A, Schmitz O, et al. Significantly better glycemic control and weight reduction with liraglutide, a once-daily human GLP-1 analog, compared with insulin glargine: all as add-on to metformin and a sulfonylurea in type 2 diabetes. Abstract presented at San Francisco, CA: American Diabetes Association 68th Scientific Sessions; June 6-10, 2008.

64. Chang AM, Jakobsen G, Sturis J, et al. The GLP-1 derivative NN2211 restores beta-cell sensitivity to glucose in type 2 diabetic patients after a single dose. Diabetes. 2003;52(7):1786-1791.

65. Mari A, Degn K, Brock B, Rungby J, Ferrannini E, Schmitz O. Effects of the long-acting human glucagon-like peptide-1 analog liraglutide on beta-cell function in normal living conditions. Diabetes Care 2007;30(8):2032-2033.

66. Degn KB, Juhl CB, Sturis J, et al. One week's treatment with the long-acting glucagon-like peptide 1 derivative liraglutide (NN2211) markedly improves 24-h glycemia and alpha- and beta-cell function and reduces endogenous glucose release in patients with type 2 diabetes. Diabetes. 2004;53(5):1187-1194.

67. Drucker DJ, Buse JB, Taylor K, et al. Exenatide once weekly versus twice daily for the treatment of type 2 diabetes: a randomised, openlabel, non-inferiority study. Lancet. 2008;372(9645):1240-1250.

68. Kim D, MacConell L, Zhuang D, et al. Effects of once-weekly dosing of a long-acting release formulation of exenatide on glucose control and body weight in subjects with type 2 diabetes. Diabetes Care 2007;30(6):1487-1493.
69. Eli Lilly. Eli Lilly Investment community Update. December 11 2008. Accessed on: March 10, 2009. Available from: http://files. shareholder.com/downloads/LLY/544477551×0×258459/5acdc123b0e7-498c-ab5c-92c599f205f2/Eli\%20Lilly\%2012-11-08.pdf.

70. Baggio LL, Huang Q, Cao X, Drucker DJ. An albumin-exendin-4 conjugate engages central and peripheral circuits regulating murine energy and glucose homeostasis. Gastroenterology. 2008;134(4):1137-1147.

71. ConjuChem. PD-DAC ${ }^{\mathrm{TM}}$ : Exendin-4 (CJC-1145-PC). 2009. Accessed February 7, 2009. Available from: http://www.conjuchem.com/.

72. GlaxoSmithKline. GSK initiates phase III programme for novel type 2 diabetes medication, Syncria ${ }^{\circledR}$ (albiglutide). February 17, 2009 Accessed March 31, 2009. Available from: http://us.gsk.com/html/ media-news/pressreleases/2009/2009_pressrelease_10025.htm.

73. Novo Nordisk. Once-weekly GLP-1 analogue (NN9535). 2009. Accessed March 7, 2009. Available from: http://www.novonordisk. com/science/pipeline/rd_pipeline.asp?showid=10.

74. F-Hoffmann-La Roche Ltd. Roche moves investigational diabetes drug, Taspoglutide, into Phase III clinical trials. June 10, 2008. Accessed March 28 , 2009. Available from: http://www.roche.com/med-cor-2008-06-10-e.pdf.

75. Sanofi-Aventis. New diabetes compound AVE0010 showed clear dose response results with once-a-day injection in phase IIb study. June 7, 2008 Accessed March 28, 2009. Available from: http://se.sanofi-aventis.com/live/ se/sv/layout.jsp?cnt=A920FF21-6EA2-42A0-80BE-E242E4D1E088.

76. Merrion Pharmaceuticals. Merrion announces license agreement with Novo Nordisk to develop oral formulation of GLP-1 receptor agonist(s). January 16, 2009. Accessed January 16, 2009. Available from: http:// www.merrionpharma.com/archive/Merrion_NN_GLP-1.pdf.

77. Nauck MA, Duran S, Kim D, et al. A comparison of twice-daily exenatide and biphasic insulin aspart in patients with type 2 diabetes who were suboptimally controlled with sulfonylurea and metformin a non-inferiority study. Diabetologia. 2007;50(2):259-267.

\section{Publish your work in this journal}

Diabetes, Metabolic Syndrome and Obesity: Targets and Therapy is an international, peer-reviewed open-access journal committed to the rapid publication of the latest laboratory and clinical findings in the fields of diabetes, metabolic syndrome and obesity research Original research, review, case reports, hypothesis formation, expert opinion and commentaries are all considered for publication. The manuscript management system is completely online and includes a very quick and fair peer-review system, which is all easy to use. Visit http://www.dovepress.com/testimonials.php to read real quotes from published authors. 